\title{
Sceattas in Anglo-Saxon Graves
}

\section{BY CHRISTOPHER SCULL ${ }^{1}$ and JOHN NAYLOR ${ }^{2}$}

Anglo-Saxon silver pennies (sceattas) are rare as grave goods but their provision was a regular element of burial practice in a small minority of later 7th-century furnished inhumations and later burials. Although the number both of coins and burials is very small they show patterns of deposition and treatment that have both a cultural and a broader chronological significance. This sample provides a window on social and symbolic attitudes to the coinages as elements of the broader material culture of contemporary society, and constitutes important corroborating evidence that the Primary Phase issues embodied a new degree of monetization in 7th-century England.

Sceattas from Anglo-Saxon graves have not received the same attention as other classes of grave goods or other aspects of the furnished inhumation rite. Indeed, hitherto they have been studied almost exclusively from a numismatic perspective. Despite numismatic interest, there is no published catalogue of sceattas from burials, little archaeological discussion of the coins as elements of the grave assemblages, nor any detailed analysis of their social contexts and significance: archaeological commentary has been largely confined to noting bag groups or taking coins as indicating a terminus post quem for the burials in which they occur.

Numismatic discussion of grave finds has tended to follow the lines set by Stuart Rigold, who included groups of two or more sceattas from burials as hoards in his 1960 and 1966 publications, where the emphasis was on the co-occurrence of types in closed contexts as evidence for the relative sequence of issues and chronology, and who undertook a brief survey of coins in Anglo-Saxon graves in his 1974 paper in Coins and the Archaeologist. ${ }^{3}$ More recent discussions, usually as specialist contributions in excavation reports, have rarely gone much beyond identification, date and numismatic context, and a brief list of some archaeological comparanda. ${ }^{4}$ Those reporting on coins cannot be blamed for adhering to brief and focussing on numismatic questions, and in view of the small number of sceattas typically known from any individual cemetery it is not surprising that archaeological discussion in excavation reports has not addressed the broader picture. There is, however, a need to integrate numismatic and archaeological perspectives by treating coins from graves as elements of contemporary material culture rather than items of primarily numismatic interest.

If the treatment of sceattas from graves has not moved on much since Rigold's publications,${ }^{5}$ the broader contexts of understanding against which we should consider them have. Excavation has increased the known corpus of burials with sceattas, and modern standards of archaeological recording mean that the physical contexts and associations of these coins are securely established; there is, therefore, a larger and more robust sample available for study (Tab 1). We also now have a much clearer understanding of the chronology and character of burial practice in the 7th century, largely as a result of the project published as Anglo-Saxon Graves and Grave Goods of the 6th and 7th Centuries AD: a Chronological Framework. ${ }^{6}$ Alongside this, the massive increase in data from metaldetecting and the Portable Antiquities Scheme ${ }^{7}$ has prompted re-appraisal of the social and 
monetary uses of coinage in southern and eastern England from the later 6th century, ${ }^{8}$ and allows us to calibrate the culturally-selective provision of coins in burials against real patterns of use and coin loss.

In this paper we aim to address three main questions in order to characterise the use of sceattas in burial practice and, through this, to investigate some aspects of the broader social and monetary dynamics of the 7th and 8th centuries. What does the occurrence of sceattas in burials tells about burial chronology and numismatic chronology? How are sceattas used in the burial rite and what are their social meanings in this context? How does their social use in burial ritual compare with the broader picture of coin use in contemporary societies?

In concentrating on sceattas from burials we recognise the dangers of isolating the material from longer-term monetary history and traditions of coin deposition in furnished inhumation. However, we believe that our approach is justifiable and useful. The earliest silver coinages represent a significant monetary development that must have embodied, and influenced, changes in social attitudes to wealth and to its symbolic expression.

Previous discussions of coin-use in 7th-century burial practice have suffered from crude archaeological chronology and have not always differentiated in sufficient detail between re-used Roman coins, Continental gold issues and sceattas. ${ }^{9}$ Although mindful of the broader and longer-term contexts, we believe that the use of sceattas in burials therefore needs to be properly addressed in its own right as a contribution to the monetary and social histories of 7th- and 8th-century England.

\section{NUMISMATIC TERMINOLOGY AND CHRONOLOGICAL CONVENTIONS}

The sceatta coinage has for many years been classified by 'Series' - groups of stylisticallyrelated coins seemingly minted in the same area - and broadly divided between early and later periods of production, the 'Primary' and 'Secondary' Phases. ${ }^{10}$ Individual Series are often divided into a number of varieties. We follow recent numismatic convention to include the issues spanning the transition from gold shillings to silver sceattas, that is issues known from their inscriptions as Pada and Vanimundus and the 'Constantine' types with low gold content, as a 'Pre-Primary' or 'Transitional' Phase. ${ }^{11}$ Anna Gannon has most recently summarised current thinking on numismatic dating which would see issues of the 'PrePrimary' or 'Transitional' Phase issued and circulating c 675-680, and would attribute issues of the Primary and Secondary Phases to c $680-710$ and c 710-760 respectively. ${ }^{12}$ Within the Primary Phase it is possible to identify earlier and later Series, and within the Secondary Phase to attribute Series to early, mid and late sub-phases. ${ }^{13}$

We generally examine and discuss the coins within our sample by Series, and in some instances by Phase. We are aware that this may risk oversimplifying a more complex picture but it is certainly arguable that the received typologies for some Series over-elaborate relatively uniform designs and this is especially true for those of Series A and Series BI which form the bulk of our corpus and whose internal dating differs little if at all between varieties. ${ }^{14}$ We are confident that for the purposes of this exercise our approach is not seriously misleading, and given the similarities of design, chronology and likely circulation of these types it seems highly unlikely that minor variations between, for example, what we classify as Series Bla or Blb would have affected the choices that early medieval people 
made in selection for burial. We do, however, discuss the relationships and sequence of specific types in more detail as necessary to support our arguments or clarify issues of interpretation.

For burial chronology we follow the phase model published in Anglo-Saxon Graves and Grave Goods of the Sixth and Seventh Centuries: a Chronological Framework which establishes a sensitive and robust archaeological chronology for furnished inhumations and associated material culture types of the mid-6th to later 7 th centuries. ${ }^{15}$ The new model, though, is not without its problems and issues, one of which is a small but significant disagreement between radiocarbon dating and coin-dating of up to 20 years at the very end of the furnished burial sequence, something that affects only graves with issues of the PrePrimary and Primary Phases. Scientific dating and chronological modelling indicate that the practice of formal furnished inhumation had been abandoned by c AD 680 if not before. Conventional numismatic dating, on the other hand, would suggest that a minority of the latest furnished graves might be as late as C AD 700. Scientific dating and chronological modelling would thus suggest that conventional numismatic dating of the earliest sceattas may be perhaps 10-20 years too late, whereas some of the scientific dates for the burial of these coins in graves are unacceptably early according to current numismatic chronology: Tab 2 summarises the different strands of evidence as they bear on our sample of burials. These issues, and the interpretative and research challenges they pose, are discussed and debated in very considerable detail in the project publication. ${ }^{16}$ We do not intend to pursue them further here because, whatever the possible resolutions of this discrepancy between absolute chronologies, the relative numismatic phase sequence and the relative archaeological phase sequence are wholly compatible and congruent with each other.

\section{BURIALS WITH SCEATTAS}

Our sample consists of 137 coins from 28 burials (Appendix A; Figs 1-3), of which almost half come from just four graves at Bridge, Kent. This includes silver coins of the Pre-Primary Phase ( $\mathrm{Pa}$ and $\mathrm{Va}$ ) and a small number of contemporary base copies and a silver sheet pressing. In all cases the provenance, context and associations of the coins are secure. The quality of information is variable, however, and the biological sex or age-at-death of the individual is not always known. In the absence of biological information, judgement has been made on the basis of gender-expression through grave goods (not possible for otherwise unfurnished burials) and from the stature of the individual as inferred from grave size and the disposition of any artefacts within the grave. At Valetta House, Broadstairs, contemporary examination of the skeleton identified it as male but the recorded association with keys or girdle hangers, if correctly identified, would suggest expression of feminine identity and most probably a female corpse: only re-examination of the skeleton would resolve this.

At least 36 further coins which are recorded or suggested as coming from burials are excluded from our detailed analysis because precise provenance and associations are insecure or unknown (Appendix B). ${ }^{17}$ We include three sceattas recorded as coming from burials at Ozengell (Kent) in this group not because there is any reason to doubt that they were grave finds, or that two (although which two is unclear) were from the same grave, but because what little further information there is about context and grave associations is 
contradictory in some respects. Similarly, there is no further information about coins recorded as from burials at Faversham (Kent). ${ }^{18} \mathrm{~A}$ burial provenance has been suggested, and has been accepted or considered likely by numismatic authorities, for finds from Thorpe Bay, Southend-on-Sea (Essex), Birchington (Kent) and Milton Regis (Kent), but the evidence is not conclusive and both Thorpe Bay and Birchington include coins of Series $\mathrm{C}$ not seen in any of the certain grave finds. At Southend there is uncertainty over the context and even the number of coins originally recovered and this could equally well be a hoard as a burial group. At Birchington, Roach Smith records only that "the person from whom Mr Rolfe procured them asserted that they were found together" with an Iron Age coin. ${ }^{19}$ The three gold filigree pendants from Milton are more likely than not to come from a high-status female burial, and it is entirely plausible that they, and any or all the 20 sceattas with which they are said to have been found, may have been elements of a single grave group, but this cannot be demonstrated and it is possible that the finds derive from more than one burial, or from a hoard, or from both. ${ }^{20}$ Finds from Marine Parade, Southampton (Hampshire) and Caister-on-Sea (Norfolk) may be from disturbed graves but there is no direct evidence for this and again they include types not seen in secure grave assemblages. The sceattas from graves at Repton (Derbyshire) and North Elmham (Norfolk) may be considered residual. It should be emphasized that the finds from Ozengell (where a burial provenance is certain), Faversham and Milton (which are plausibly interpreted as coming from burial assemblages) and Repton (which may have been intentionally placed with the body) are entirely consistent with the patterns of burial provision identified by our analysis of the coins from secure burial contexts, and we include Ozengell in our distribution maps (Fig 2).

All sceattas from known burials are from inhumations, cremation having been abandoned in England before the first sceattas were minted. ${ }^{21}$ Twenty of these graves were burials according to the funerary tradition of formal clothed and furnished inhumation, in which the deceased was buried clothed and accompanied by costume accessories and other items symbolic of social identity and status. ${ }^{22}$ Among these are two double burials of adult and child, at Finglesham (Kent) grave 1 and Bridge (Kent) grave 6, but in both cases the coins were clearly associated with the adult. The remaining seven burials can be attributed securely to the funerary traditions current after the abandonment of formal furnished inhumation in the later 7 th century; ${ }^{23}$ in most cases this is supported by other archaeological information, and in all cases by the termini post quos for burial provided by the coins themselves. Although it may seem counter-intuitive to refer to these as 'unfurnished', given that coins were buried as grave goods, we will use this term in what follows as a convenient shorthand that distinguishes them from earlier clothed and furnished inhumations.

The CoIns from the EARLIER GRAVES

The earlier group of burials with sceattas belongs to the latest phase of formal furnished inhumation; these are graves of Hines and Bayliss Phases AS-FE (female) and AS-MF (male). ${ }^{24}$

Only issues of the Pre-Primary Phase and of Primary Phase Series A and B are known from these furnished graves. ${ }^{25}$ Issues of the Pre-Primary Phase are represented by 10 coins from six burials (eight $\mathrm{Pa}$, one Va and one 'Constantine'/Pa mule). Of these, five (50 per-cent 
of the sample) appear to be contemporary base imitations and six (60 per-cent) are looped or pierced for suspension. As far as we know, no gold or pale gold English shillings are known from securely-recorded grave contexts (although there is a pale-gold shilling pierced for suspension among finds from Faversham recorded as from burials, ${ }^{26}$ and a recent group of metal-detector finds from North Yorkshire, probably elements of a burial assemblage, includes a gold shilling of the York group ${ }^{27}$ ) and they are represented in our sample only indirectly by the base imitation 'Constantine'/Pa mule from Buttermarket, Ipswich (Suffolk) grave 4275 , which was associated with a base imitation of PallI.

Issues of the Primary Phase are represented within this group of burials by 102 coins from 14 graves. None is mounted or pierced for suspension and there are only two imitations, a base copy from Harford Farm, Caistor St Edmund (Norfolk) grave 18 and an impressed foil from St Mary's Stadium, Southampton grave $4202 .{ }^{28}$ These finds represent a consistently narrow range of types: only Series $A$ and $B$ are present and only the initial substantive issue of Series B - type BI - is represented: no example of the earliest and less common variety $B X$ has been recorded from a burial. Only a single possible example of the slightly later Series BII is known from a burial, at Bridge. Series F, a contemporary issue with Series $A$ and $B I$ is not represented in our burial sample although it did circulate in small numbers in Kent and Suffolk.

Within the closed contexts represented by the furnished burials issues of Series $A$ and Series B occur together but in no case are issues of the Pre-Primary Phase found with those of the Primary Phase. This must in part be a function of relative chronology and currency in circulation but when taken with the very different frequency of copies and the differences in usage between the two groups, discussed in more detail below, it also suggests that issues of the Pre-Primary and Primary Phases were accorded different cultural values and social functions within the burial rite.

\section{The Coins from the LAter Graves}

The latest of these graves is the mid-8th-century chest-burial at Spofforth, where the deceased woman appears to have been buried clothed, with an iron key and a sceat of Series $Y$ issued by Eadberht of Northumbria (737-58). The other graves in this group were simple unaccompanied inhumations with no grave goods other than the coins themselves. At Clifford Street, Southampton, and St Pancras Church, Canterbury, single coins were buried with children, and a single coin was buried with the body at Kingston Down. The two sceattas from the Wrotham burial were pierced and found at the neck of the skeleton, suggesting that they may have been worn as a necklet. At Garton Slack the coins appear to represent a pouch or bag group under the pelvis; at Steward Street, Spitalfields, the coins appear to represent a pouch or bag at the right shoulder.

Of the 24 coins from these burials, 18 are from the pouch or bag groups at Garton and Spitalfields. Two, from Clifford Street, Southampton and Kingston Down, are later Primary Phase coins (respectively a Series W and Continental Series D type 2c): the significance of these is discussed in greater detail below. The remainder are all issues of the Secondary Phase. On current numismatic dating only two of the burials, Southampton and Kingston 
Down, can be earlier than c AD 710. Canterbury, Wrotham and Garton Slack can be no earlier than c 720, Spitalfields no earlier than c 730, and Spofforth no earlier than c 740.

\section{BURIAL SEQUENCE AND CHRONOLOGY}

Most furnished burials containing sceattas (at least 14 or 15 of the 21 graves in our sample) were female. It seems unlikely that any of the male graves with sceattas were significantly earlier than their female counterparts and so we have adopted the inception of the latest phase of furnished female burial (AS-FE) as representing the terminus post quem for male as well as female graves with sceattas. This model would see Pre-Primary and Primary Phase issues being used in furnished burial no earlier than cal AD 625-650 (at 95\% probability) or cal AD 635-650 (at 68\% probability) and no later than cal AD 660-680 (at 95\% probability) or cal $A D$ 660-675 (at 68\% probability) for the female burials and cal AD 660-685 (at 98\% probability) or cal AD 665-680 (at 68\% confidence) for the male burials. As noted above, standard numismatic dating places the Pre-Primary Phase (silver issues of 'Constantine' type and Series Pa and Va) and early Primary Phase (including Series A and BI) to around c 675-700.

It may be tempting to argue that graves with Pre-Primary Phase issues are likely to be earlier than those with Primary Phase issues, and certainly they must have slightly earlier termini post quos on current numismatic understanding. However, we cannot at present use this to refine further the archaeological chronology for furnished burials. Both Pre-Primary and Primary Phase coins, though mutually exclusive in grave contexts, are associated with the same broader suites of material culture types within archaeological phases AS-FE and AS-MF, including Merovingian solidi of the 630s-650s which have been adapted as jewellery. The association of sceattas with earlier Merovingian issues has been cited to warn against the over-simplified use of coins in archaeological dating. ${ }^{29}$ In the case of Boss Hall grave 93, for example, conventional dating of the BI sceat would imply that the mounted solidus of Sigibert III may have been buried 40 years or more after it was minted. ${ }^{30}$ However, while accepting that the adapted Merovingian issues were curated, and that they and the sceattas were not in contemporary circulation as coinage, it should be noted that these associations could accommodate a slightly earlier date for the sceattas than current numismatic dating would envisage.

Their mutually exclusive provision as grave goods would appear to represent the wider replacement of Pre-Primary Phase issues by the first issues of Series A and B, and supports the view that this was a rapid and significant threshold of monetary change. It does not, however, translate into an identifiable chronological horizon within the archaeological burial sequence, although we can propose that burials containing issues of Series A and B are among the very latest furnished inhumations. This should not be considered surprising. There is no reason why a monetary change, however significant, need affect the broader aspects of culture and identity that are signalled through the materiality of furnished burial, and we need to recognise both the near-contemporaneity of the latest Pre-Primary Phase and first Primary Phase issues, and the complexities arising from the time between minting and deposition (notoriously difficult to judge) which were in turn governed by the use-life and circulation of the individual coins. For example, Primary Phase coins from graves could, in principle, have been deposited very soon after minting whereas Pre-Primary Phase issues 
used as jewellery may have had a longer use-life, in circulation as coins and then as pendants, before deposition. In some cases, therefore, earlier coins with a longer use-life may have been deposited after later issues with a short period of circulation.

We can, however, safely conclude that silver issues of 'Constantine' type, Series Pa and Va were in circulation, and being acquired (and copied) and deposited, during the final phases of the furnished inhumation rite and that the practice of formal furnished inhumation was abandoned during the currency of the earlier, if not the earliest, issues of the Primary Phase - on current numismatic dating by c AD 700, on archaeological dating by c AD 680. Two critical pieces of evidence here are the Primary Phase Series W from a child's grave at Clifford Street, Southampton and the Continental Series D (type 2c) from Kingston Down, Kent. ${ }^{31}$ The former is an early grave in a small cemetery within the burial tradition that immediately post-dates the abandonment of formal furnished inhumation; ${ }^{32}$ the latter appears to be part of the latest phase of the larger barrow cemetery. Both finds support the view that the culmination of the change in burial practice from furnished to unfurnished occurred during the currency of Primary Phase issues.

The latest phases of furnished burial straddle the threshold of change between issues of the Pre-Primary and Primary Phases, and coins of both Phases were deposited in these graves. The burials with sceattas represent a period of $15-45$ years (95\% confidence) or 20 35 years (68\% confidence), ${ }^{33}$ and current numismatic dating would see all types represented in furnished burials as being produced within a period of c 25 years. Because the coins were deposited as elements of symbolically-laden material culture assemblages, the burial sequence therefore provides an opportunity to examine monetary history from the perspective of social practice with an unusual degree of chronological precision.

\section{THE MONETARY BACKGROUND}

If we are to understand the social function of coinage in the funerary rite it is important to understand the extent to which our sample of coins selected for burial is representative, or not, of broader contemporary patterns of circulation and loss.

\section{Geographical Distributions AND the Composition of Burial Assemblages}

Finds of Pre-Primary Phase sceattas and Primary Phase Series A and BI/BX are distributed widely across eastern England from the Wash to Kent (Figs 4-5). ${ }^{34}$ With only a few exceptions Pre-Primary Phase coins are not known west of Kent or East Anglia. Finds of Series $A$ and $B$ are most plentiful across eastern Kent and coastal regions of Suffolk and Essex, accounting for approximately one-third (36 per-cent) of single finds of Series A, 40 per-cent of Series B, and almost half (47 per-cent) of Series Pa and Va. These were the core areas for monetisation, with adjacent areas developing a little more slowly, ${ }^{35}$ but early sceattas, especially of Series A and B, are also known in reasonable numbers from other areas especially around the fen-edge of Suffolk and Cambridgeshire and in north-west Norfolk.

The geographical distribution of graves containing sceattas is significantly more constrained than that of stray finds (Figs 1-5) and shows differences between earlier and 
later burials. The distribution of furnished burials with sceattas is predominantly coastal with only Lechlade inland. This find is the only example of a Pre-Primary Phase coin known from the Upper Thames Valley, where there is also a relatively low occurrence of early Primary Phase types (Series A, BX/BI and F). ${ }^{36}$ It is likely that the coin did not enter the region as circulating currency but as a piece made or modified as part of a necklace, and it can be considered anomalous within the distribution of burial finds.

There are two main clusters of furnished burials with Pre-Primary and Primary Phase sceattas, one in eastern Kent and the other in south-east Suffolk centred on Ipswich and the Gipping Valley (Figs 1-2). Three Pre-Primary Phase burials are known in eastern Kent, all from separate cemeteries, and eight early Primary Phase burials from four cemeteries, with four graves from the cemetery at Bridge. The Suffolk cluster has two Pre-Primary Phase burials from the Buttermarket cemetery, associated with the earliest trading settlement at Ipswich, two early Primary Phase burials from Boss Hall, $2.5 \mathrm{~km}$ upriver of the trading settlement, and two burials with coins at Coddenham, c $10 \mathrm{~km}$ north of Ipswich. The only other furnished burials with Pre-Primary or Primary Phase coins are from St Mary's Stadium, Southampton, associated with the earliest phases of the Hamwic trading settlement, Springhead, overlooking the south shore of the Thames estuary in western Kent, and Caistor St Edmund, a location with good riverine access to the North Sea coast where cemeteries and metal-detector finds suggest an important early-middle Anglo-Saxon site. ${ }^{37}$ Unfurnished graves with later Primary Phase and Secondary Phase coins in Kent and at Southampton, which include the earliest coins from this group of burials, are consistent with the earlier distribution but no such graves are yet known from East Anglia. Burials north of the Humber at Garton-on-the-Wolds and Spofforth, and Spitalfields in London, are later and in areas which had not seen sceattas used as part of the furnished inhumation rite. Spitalfields, though, fits the broader pattern of a predominantly coastal or estuarine location.

There is some correlation with what are perceived as core areas of early monetization but the broader distribution of finds shows that sceattas circulated and were lost over a much wider area than their deposition in furnished burials. It should be emphasised, too, that the geographical distribution of furnished burials with sceattas is very much more restricted than the contemporary furnished inhumation rite. ${ }^{38}$ The provision of sceattas in burial cannot therefore be seen as a simple proxy for coin circulation or usage, but was a more specific and geographically-circumscribed aspect of funerary practice. That being so, it is important to consider whether the coins in burials are broadly representative of the currency circulating in those regions or whether specific types were preferentially selected.

Eastern Kent provides the largest sample of furnished burials with sceattas and five different types are represented (Series Pal, Pall, PallI, A and BI). Series Pall is the most common Pre-Primary Phase type in burials and in the stray finds from eastern Kent, and the proportion of Series A and BI in burial assemblages is also similar to that in the broader corpus of stray finds (Fig 6). In Suffolk the Pre-Primary Phase coins from burials also fit the pattern of the stray finds, with Series Palll and the 'Constantine' types most common. However, within the later assemblages there are eight examples of Series BI but only a single Series A, whereas the latter is the most common stray find (Fig 7). Whether this indicates a conscious preference for Series $\mathrm{BI}$ in burials or is a product of a very small burial sample is hard to assess but it does contrast with Kent where there is nothing to suggest 
that either Series A or BI were preferentially selected or deliberately excluded. Coins from the later unfurnished burials also appear to be broadly representative of circulating issues. Thus the assemblage from Garton-on-the-Wolds fits the broader pattern in Deira where Series $\mathrm{J}$ and $\mathrm{G}$ are both well represented at Fishergate, York and the nearby site around Sledmere, ${ }^{39}$ and where another example of the unusual Series $R$ variant is known from East Yorkshire at Sheriff Hutton. ${ }^{40}$ The two burials containing Series $S$ and T coins at Steward Street, Spitalfields and Wrotham are also within the known circulating areas for these types, as is the Series $Y$ at Spofforth.

With the possible exception of early Primary Phase issues in south-east Suffolk the provision of sceattas in burial appears to reflect contemporary patterns of circulation and availability rather than the deliberate selection of types for their specific iconographic, symbolic or socio-political associations. This would argue that in areas where sceattas were buried as part of the furnished inhumation rite their significance was linked to their circulation as coinage, but that their use as grave goods in this way was a geographicallycircumscribed minority element of contemporary mortuary practice. The strong association with coastal areas and coastal or estuarine locations, and with the earliest phases of the major emporia at Southampton and Ipswich, suggests that the provision of sceattas in burial was linked to particular socio-economic conditions in the coastal zones of south-east England, and expressed social identities specific to coastal- and maritime-orientated communities. This is discussed further below.

\section{RATES OF ACQUISITION AND BURIAL}

Coins from the furnished burials represent 82 per-cent of sceattas in our sample (113 coins) from 75 per-cent of graves ( 21 burials). According to conventional numismatic chronology these represent deposition over c 25 years (c AD 675-700), which would equate to the burial of one coin every 11-12 weeks ( 4.5 coins buried per year) and one person buried with coins every 14 months ( 0.80 burials per year). Coins from the unfurnished burials represent 18 per-cent of sceattas in our sample (24 coins) from 25 per-cent of graves (seven burials). According to conventional numismatic chronology these must represent deposition over at least 40 years (c AD 700-740), which would equate to the burial of one coin every 18 months ( 0.6 coins buried per year) and one person buried with coins every five-and-a-half years ( 0.18 burials per year).

The averaged deposition rates for sceattas placed in burials and individuals buried with sceattas are thus around seven and four times greater respectively for the earlier furnished inhumations than for the later unfurnished inhumations. Both Pre-Primary and Primary Phase issues were circulating and available for selection as grave goods during the final phases of formal furnished inhumation and it is therefore probable that the greater numbers of Primary than Pre-Primary Phase issues known from burials reflects at some level the relative numbers of coins minted and in circulation. Issues of the Pre-Primary and Primary Phases were however buried in greater numbers and more frequently than those of the Secondary Phase. This runs counter to our understanding of the numbers minted and in circulation at any one time but it does conform to the change in burial practice. The PrePrimary and Primary Phase coins were buried in disproportionately greater numbers and more frequently because they were part of the material culture kit used in formal furnished 
inhumation but after its abandonment the provision of coins in burials was less common and less frequent.

\section{THE PROVISION OF SCEATTAS IN BURIAL}

The provision of sceattas as grave goods has potential to offer insights into relationships between monetary values and other aspects of social practice. Are there significant differences in the funerary deposition of sceattas that might indicate variations in symbolic valency and broader changes in the social or monetary functions of coinage?

Our sample of burials is too small, and the information available too inconsistent, to make it worthwhile seeking to identify statistically-significant associations between the provision of sceattas as grave goods and aspects of the life-course and social identity that can be inferred from biological data, recurrent material culture associations, or the manner and precise location of deposition. There are, however, a number of highly suggestive patterns that allow insights into the symbolic use of the coins in burial, and shed some light on social attitudes to coinage and the social contexts of coin use.

USAGE IN THE GRAVE

\section{Pre-Primary Phase issues from furnished inhumations}

The provision of Pre-Primary Phase issues as grave goods shows a very clear gender distinction. Four of the six graves are those of women or girls and in all cases the coins from these burials have been adapted for suspension. In Finglesham grave 7, Buckland grave 110 and Buttermarket grave 4275 they were found with other pendants and beads as components of necklets; at Finglesham this was worn on the corpse, and at Dover and Buttermarket deposited in a bag by the legs or feet. The precise position of the base imitation Va from Lechlade grave 179 was not recorded, but it was from the area of the head or neck and so almost certainly was worn as part of the necklet that included a gold filigree pendant. ${ }^{41}$ These coins were being used as jewellery in women's graves in exactly the same way as the majority of imported gold issues from 7th-century burials. ${ }^{42}$ Indeed, a looped solidus of Sigibert II or III is also part of the necklace in Finglesham grave 7. In female graves, then, the latest issues in the tradition of Insular gold and pale gold coinages were used, to a great extent, in exactly the same way as earlier imported gold coins.

The two other furnished burials with Pre-Primary Phase issues, Buttermarket grave 1356 and Sarre grave 226 were, on the basis of the grave goods, probably those of males. Each of these individuals was buried with two Pa coins, none of which was adapted for suspension. In Buttermarket grave 1356 the two coins (one of which is a base imitation) formed part of a purse group (purses, worn at the waist as part of costume, may be distinguished from bags by their characteristic form and metal fittings). It is tempting, but undemonstrable, to suppose that this may also have been the case at Sarre.

This group of 10 coins includes four base imitations. Whether these were strictly speaking forgeries, intended to deceive in monetary transactions, is open to question, although there is strong evidence for the contemporary counterfeiting of sceattas. ${ }^{43}$ Michael 
Metcalf has argued that the imitation Va from Lechlade grave 179 was made as a pendant and it seems likely that the two looped copper-alloy imitations from Buttermarket were made to be part of the necklet. ${ }^{44}$ This would argue that the issues being imitated were seen in some communities as appropriate or desirable as components of female dress jewellery to the extent that low-value copies were acceptable if the real thing was not available. This may in turn suggest that there was a specific social value attached to these early issues related to display in the female sphere. The base imitation Pa from Buttermarket grave 1356 is more plausibly explained as a forgery but if the provision of two coins in a purse group had a symbolic significance in burial then it may have been made specifically for a funerary purpose; alternatively, symbolic deposition in burial may have seemed like a good way of passing bad money.

\section{Primary Phase issues from furnished inhumations}

The provision of Primary Phase issues as grave goods shows an even stronger gender distinction in usage: of the 14 graves at least nine are female and only three unequivocally or probably male. The number of coins in any one burial varies from one to 21 , and location in the grave varies, but none has been adapted for use as jewellery. Where dress jewellery was worn on the corpse (as at Bridge graves 5, 6 and 9, Coddenham grave 8 and St Mary's grave 4202) the coins were placed elsewhere, and at Boss Hall grave 93, where the coin appears to have been associated with beads and pendants as elements of a box assemblage, the lack of any evidence that it was adapted for suspension indicates that it was not a component of the dress jewellery. In contrast to the ways in which imported gold coins and Pre-Primary Phase issues were used in burial, these Primary Phase issues appear not to have been considered appropriate for use as jewellery and to have been deposited as coins in their own right.

Precise placement in the grave shows some variation. At Boss Hall grave 93 and Harford Farm grave 18 the coins were associated with boxes by the head of the corpse, and the coins from St Mary's grave 4202, found in the area of the chest, away from the cluster of dress jewellery at the neck, may have been in a bag. The coins from Coddenham grave 8 appear to have been in a purse worn at the waist, and those from Boss Hall grave 2014/2 in a bag deposited as part of a chatelaine assemblage at the waist or thigh. The published account suggests that the coins from Breach Down were also part of a chatelaine group. In all four burials at Bridge (three female and one male) the coins had been placed in textile bags at the foot of the corpse. These graves are interpreted as belonging to a small family cemetery and the very consistent use of coins in the burial rite suggests a specific local practice and close contemporaneity. The coin from St Peter's is the only example placed in the mouth. This practice is known from Roman world and found in Merovingian-period burials on the Continent but is not common in 5th- to 7th-century inhumations in England. ${ }^{45}$

The base imitation from Coddenham grave 30 cannot be identified to type but its context may suggest that it is more likely to copy a Primary Phase coin than an earlier issue. As at Boss Hall grave 93, it was deposited with a collection of pendants and other valuables, although in a bag on the torso of the corpse rather than a box at the head. The clear distinction from earlier practice is emphasised by the fact that in both graves the assemblage of valuables included a Merovingian gold coin adapted for use as a pendant. 
The two sceattas from the male burial at Springhead are interpreted as having been in a purse. Two other male or possible male graves contained assemblages of eight sceattas. At Finglesham grave 145 this was part of a purse group. It seems likely that the coins from Valetta House, Broadstairs were a pouch or bag group but this cannot now be demonstrated.

This group of coins includes two contemporary imitations in addition to that from Coddenham grave 30, from Harford Farm grave 18 and St Mary's grave 4202. The pairing of a genuine coin with a base imitation at Harford Farm is like that at Buttermarket grave 1356 and suggests that the imitation may have had a similar symbolic or compensatory function. The impressed silver foil from St Mary's was probably made specifically for burial, ${ }^{46}$ and this also seems the most likely explanation for the imitation from Coddenham grave 30 .

\section{Issues from unfurnished inhumations}

Two main modes of provision are apparent within this group of seven graves, single coins and pouch or bag groups, the only exception being the burial at Wrotham where the apparent suspension of coins on a necklet evokes earlier burial custom. Single coins were buried with children at Clifford Street, Southampton and St Pancras, Canterbury, and with older juveniles or adults at Kingston Down and Spofforth. At Garton Slack the coins were found under the pelvis, apparently associated with organic remains, and at Spitalfields the coins were grouped together in the right armpit, probably in a bag. An 11th-century execution burial at Stockbridge Down, Hampshire, had a group of pennies at the armpit; ${ }^{47}$ the possibility that the Spitalfields grave was an execution burial cannot be ruled out.

\section{GENDER AND AGE-AT-DEATH}

Within the furnished inhumation rite the provision of sceattas was predominantly an attribute of adult female burials. The only burials of children or juveniles are Finglesham grave 7 and St Peter's grave 362, both female, and the little girl at Finglesham was unusual in being accorded burial with full and elaborate adult kit, suggesting that she was from a family of some importance. This pattern is entirely consistent with the status ideologies expressed in the latest phases of formal furnished inhumation, which was more commonly accorded women than men and where a greater range and quantity of material culture items was typically invested in symbolising female or feminine social identities. ${ }^{48}$

Throughout the period of furnished inhumation the main, though not exclusive, mode of deposition in male graves appears to have been as elements of purse groups in which the coins themselves were the only items of intrinsic value. This contrasts with the greater variety of modes of deposition in female burials where, in addition to Pre-Primary Phase issues being used as jewellery, coins of Series A and B were deposited as elements of box and bag assemblages with other collections of valuables as well as in purse or bag groups of coins only or where the coins were the only valuables. Again, this is consistent with broader trends in contemporary furnished inhumation where the articulation of social identities through the provision of material culture items appears to have been more constrained in the male or masculine sphere than in the female or feminine. ${ }^{49}$ 
The very small sample size and lack of skeletal information precludes the identification of any such patterning in the unfurnished burials. There is a higher proportion of children, and the data would be consistent with the provision of single coins with females and children and pouch or bag groups with males, but this would rest on extrapolation from two biologically-sexed individuals (Spofforth and Spitalfields) and the material would be equally consistent with the proposition that there was no gender distinction in burial. It may be tempting to assume that the Wrotham burial provides a rare late glimpse of the continuing or intermittent use of sceattas as components of female dress jewellery, for some reason not otherwise expressed in burial since the currency of the Pre-Primary Phase issues. However, it is not known whether the Wrotham burial was male or female; the coins may have been worn at the neck but there are no associated beads and pendants; and, although pierced, they may have retained their currency value and been buried as money. We can only speculate as to the range of individual circumstances that may explain the coins in this grave.

\section{BURIAL WEALTH AND SOCIAL STATUS}

The expression of social identities in furnished burial was complex and was mediated by the circumstances and aspirations of the living but there are demonstrable correlations in the archaeological record between modes of burial and individual identities. ${ }^{50}$ There need be no simple relationship between burial wealth and rank in a hierarchical society, but significant investment in burial will at a general level reflect a kindred's ability to accumulate wealth and resource, and differential provision is likely to be significant within a status ideology that emphasises investment in burial. However, it is important to recognise that differential expressions of identity and rank in furnished inhumation operated at the level of the family and kin-group as well as the wider community and societal scales, and that there were social roles that might allow the accumulation of material wealth and local prominence that were not necessarily co-terminous with a ranked social hierarchy. ${ }^{51}$

Sceattas were deposited in furnished inhumations at a time when this was a minority burial practice that appears to have been socially circumscribed. ${ }^{52}$ As noted above, their use was largely confined to communities in coastal areas but it should also be emphasized, given the argument that the relationship between material wealth and social identities in maritime-orientated communities need not correlate with those of inland communities, ${ }^{53}$ that there is otherwise a consistency of material culture types and modes of provision that argues for a widespread coherence of status ideology and its expression in burial over much of lowland England - coastal and inland. ${ }^{54}$ To this extent, then, the evidence is consistent with these coinages circulating within, and being deposited by, higher echelons or segments of early English society. However, these are not the highest ranks and in most cases are likely to represent locally rather than regionally-important kindreds. Only Coddenham grave 30 and Boss Hall grave 93 can be considered aristocratic and in these instances only single coins (one a base imitation) were deposited with assemblages whose other elements far outweighed in value that of the individual coins. In so far as sceattas were used to articulate status ideology in burial, therefore, we may infer that this was more common among locallyimportant kindreds than regional magnates or elites. 
There is no clear correlation in the furnished graves between the numbers of coins deposited and the overall level of burial wealth expressed by the other components of the burial assemblage. The ability to acquire coined silver would have been conditioned by numbers minted and by differential proximity to core areas of minting and circulation, and by the fluctuating complexities of the networks through which social and economic transactions were enacted, and individuals linked to the maritime zone of the North Sea and Channel coasts are likely to have been preferentially situated on both counts. The motivation to acquire coined silver, and to invest it in human burial, would also depend in some measure upon the extent to which an individual or group subscribed to the value system and ideology embodied in the coinage. If, from the Primary Phase onwards, sceattas represented more specifically a monetary value than did earlier coinages then it is possible that their provision was intended to complement or compensate for, or even to replace, other forms of burial wealth, in which case a more complex and nuanced relationship between the provision of coins and other material culture types in burial is to be expected. Following from this, and from conclusions about the social and political level at which coinprovision in burial was most common, it may be that Pre-Primary and Primary Phase issues embodied a particular prestige or ideological value for those who were locally prominent but followed regional magnates. This might be related to their place in reciprocal relationships of obligations, dues and patronage, or to the ability to generate material wealth though commerce, or both.

Provision in unfurnished burials is more difficult to read: there is not the same clear articulation of social ideology through the provision of material culture items, nor a sufficient number of burials to be confident about possible trends in deposition. Chest burial is seen as a higher-status rite. ${ }^{55}$ Pouch or bag groups may symbolise wealth, or represent the disposal of personal possessions with the deceased, or both. The provision of single coins, although involving the burial of portable wealth, would appear to have a different symbolic purpose. It is possible to argue, though, that at a more general level the provision of coins represents a transformation of concerns to symbolise individual worth in burial that can be traced back through the furnished inhumation rite of the 7th, 6 th and 5 th centuries. This point is discussed in more detail below.

\section{COIN ICONOGRAPHY AND BURIAL SYMBOLISM}

It is clear that the provision of sceattas may have had a variety of meanings within the furnished inhumation rite and that these were not necessarily mutually-exclusive. Our evidence is that they were predominantly selected for burial because of their symbolic value as coins or intrinsic value as money, and that provision broadly reflects circulation. However, the coins also carried complex iconography (Fig 8) and we cannot ignore the likelihood that this was sometimes a factor in selection and one of the dimensions of intended meaning in the burial symbolism.

A deliberate iconographic emphasis seems most plausible where coins were worn as pendants (Fig 8a-c), especially where - as at Buttermarket grave 4275 and Lechlade grave 179- there is a good case that a contemporary copy may have been specifically made for the purpose. It has been suggested that the role of coins exhibiting busts, especially in profile, on necklaces or near the head, may have been amuletic, designed to deflect or 
confuse the evil eye. ${ }^{56}$ At St Mary's grave 4202 two Series B coins were recovered from the area of the chest along with a silver foil impressed with a Series B obverse. These may have been in a bag, and the foil pressing included to make up numbers, but it is at least arguable that the decision to make and bury the pressing was linked to the iconography of Series B, which combines traditional apotropaic and explicitly Christian imagery (Fig 8d). ${ }^{57}$ The coins may, therefore, have been placed on the corpse as both objects of monetary value and for their symbolism. In this respect it may be significant that the burial assemblage also included one of the cylindrical copper-alloy containers conventionally identified as 'work boxes' but now argued to be reliquaries. ${ }^{58}$

By contrast, where two or more coins were buried in purses, pouches or bags the context and associations suggest that the symbolism is primarily monetary. It is interesting, however, in view of the iconography of Series B, that in south-east Suffolk there may be some evidence to suggest that coins of Series B were selected preferentially over those of Series A(Fig 8e) for burial. It would be wrong to read too much into this because of the small sample but it raises the possibility that here iconography and belief may have influenced the selection of coins for burial even when the primary function or symbolism of provision was monetary. The single coins found by the jaw at St Peter's Tip, Broadstairs grave 362 and by the head at Clifford Street, Southampton may be examples of Charon's Obol. ${ }^{59}$ It may be tempting to suppose that iconographically-appropriate coinage was selected for such a heavily symbolic role but this is undemonstrable, although it must be noted that in both cases the iconography shows explicitly Christian imagery (Fig 8d and 8f).

\section{MONetARY VALUeS}

It has often been assumed, and stated, that sceattas occur in graves in a small number of multiples that might represent specific monetary values. Rigold first raised this in his discussion of the 'hoards' in purses, pouches or bags, suggesting that there was a recurrent pattern of five, eight or 20 coins which he interpreted as 'clearly intentional sums' that were units of account 'for legal or ceremonial payments, including nominal values of gravegoods'. ${ }^{60}$ These three figures, along with finds of two coins, have been quoted subsequently as evidence for the provision of standard amounts of money within burials, ${ }^{61}$ and Metcalf has suggested that they 'may possibly reflect the valuation of four pennies to a shilling' ${ }^{62}$ Finds of two sceattas have been seen as characteristic of provision in furnished inhumations, larger sums as a feature of the later unfurnished burials. ${ }^{63}$

These commonly-quoted conclusions are, however, open to question. Neither of the groups of 20 sceattas usually cited in this context (Milton Regis and Southend-on-Sea) can be attributed securely to a single burial or indeed to a burial at all, and there is uncertainty as to the number of coins from Southend. ${ }^{64}$ More generally, the numbers of coins in burials do not conform to a clear pattern of simple multiples. Tab 1 shows the numbers of coins found in burials by Phase. Only the provision of Pre-Primary issues, with one or two coins to a grave, shows any consistency, and it must be remembered that within this group pairs of coins include both base-metal imitations made as necklace components and elements of purse assemblages. Primary Phase issues are known from furnished burials in numbers from a single coin to 21 coins, with no more than two examples of any multiple (one, two, three, five and eight). The coin groups from Bridge are all larger but seemingly unrelated 
numerically $(12,14,17$ and 21$)$. The later finds, from unfurnished graves, are most commonly single coins, but there were eight at Garton-on-the-Wolds and 10 at Spitalfields.

The suggestion that there was a consistent pattern to the number of sceattas buried with the dead, reflecting contemporary monetary units and a shared understanding of appropriate funerary payments, is therefore hard to sustain on current evidence. This is not to argue that there were no such monetary units, or that the coins did not have a widelyrecognised monetary value, but rather that the ways in which sceattas were used to convey a range of symbolic information in burial varied with individual circumstances and that in such calculations the basic unit of account was the silver penny itself.

\section{DISCUSSION AND CONCLUSIONS: COINAGE AND SOCIETY}

Reading the archaeology is complicated by the differences in the male and female spheres as symbolised in burial but it is possible to identify in the differing treatment and use of Pre-Primary and Primary Phase coinages in mortuary practice evidence for changes in social attitudes towards coinage.

The Pre-Primary Phase coins known from female graves were treated as jewellery in the same way as earlier imported gold coins. It has been convincingly argued that these were seen as items of value, in the same way that other precious components of jewellery embodied wealth, but not as coinage in the sense of an exclusive or primary means of exchange in a monetised economy where the value of a coin is backed by political authority. ${ }^{65}$ This is of course a complex question: definitions and perceptions of value, wealth and monetisation may be multi-valent and shifting, and there is clear evidence both that gold coinage was circulating as part of a bullion economy from the earlier 6th century and that conventional wisdom has underestimated the extent of monetary circulation in the later 6 th and 7 th centuries. ${ }^{66}$ It is also clear that coins had a wider symbolic significance or they would not have been adapted or deliberately copied for use in jewellery. However, we believe that the general observation holds.

The treatment of Primary Phase issues from female graves was quite different. Even when deposited with jewellery they were no longer part of it and in most cases were placed separately within the grave. This strongly suggests that these coins were recognised as units of exchange in their own right - coinage as money - and were deposited or gifted as such. We would therefore argue that they were seen as representing transferable, alienable, wealth in a monetary sphere distinct from the wealth embodied in dress jewellery or other artefacts of intrinsic value, in other words primarily as a medium of exchange. The presence of gold jewellery, with its own bullion value, in a number of these burials further emphasises the distinction.

The evidence suggests that Pre-Primary and Primary Phase issues were deposited in male burials predominantly as elements of purse groups, and the Primary Phase assemblages are larger. In contrast with female burial there is a consistency in mode of provision across the Pre-Primary / Primary Phase threshold, but a more emphatic statement in the deposition of Primary Phase coins. This may suggest that Pre-Primary Phase issues were seen as money when circulating or used in the male sphere but that this perception was less clear cut for 
Pre-Primary than for Primary Phase issues. The more emphatic distinction in treatment in female burial suggests that a broader societal change in perceptions of the coinages may have been accompanied by a change in the relationships between female social roles and portable wealth. It can be argued that the emphatic assertion of female identities in late furnished burial was linked to an expansion of the female social sphere and female social roles. ${ }^{67}$ In this light, a new emphasis on the provision of coined money as alienable wealth, as distinct from wealth embodied in jewellery, might be seen as asserting a degree of financial autonomy.

The general argument that there was an increasing monetisation of coinage through the 7th century that culminated, or found its critical threshold, in the first true silver pennies, therefore finds support in evidence for social attitudes towards different coinages and the expression of wealth in furnished burial, and particularly in female furnished burial. There is also a cultural distinction that is congruent with the proposed numismatic and chronological threshold. In this context it is relevant to note the treatment of valuables in Bloodmoor Hill, Carlton Colville (Suffolk) grave 11, the burial of a sub-adult or adult woman of phase AS-FE. ${ }^{68}$ The deceased was buried with dress jewellery in the area of the head, and a chatelaine complex at the left side of the waist. Close to the chatelaine, and perhaps buried in a bag, was a silver strip and blank silver disc. This undoubtedly represents portable wealth and the total weight of silver is equivalent to that of 7 or 8 Primary Phase sceattas. It is possible that the silver disc is an unstruck coin flan but perhaps more likely that it was intended as a substitute coin of comparable size and fineness to contemporary silver issues. Most significant, though, is that in this case the deposition of uncoined silver both invokes coinage through the inclusion of a blank flan and is handled in burial in exactly the same way as collections of contemporary coinage. This suggests that when sceattas were not available for burial they were none the less the monetary and symbolic reference point for portable wealth.

These changing attitudes are also apparent when the provision of sceattas is compared to earlier patterns of use of coin-use in furnished inhumation. We have already noted that the adaption of Pre-Primary Phase coins for use as jewellery continues a practice seen in the treatment of earlier imported gold issues. Roman copper coins, pierced for suspension or deposited as elements of bag assemblages, occur in female graves from the later 5 th century, ${ }^{69}$ and indeed a Roman copper issue was associated with the base imitation sceat in the bag assemblage from Coddenham grave 30. To this extent, then, the use of sceattas in female burial perpetuates long-standing funerary traditions, but there are also clear differences and innovations in usage. The most significant is the burial of coins in purses or as bag groups without other valuables, something that is best explained by these issues representing monetised value in a new way. The provision of coins as money also changed their valency when buried with other valuables as parts of bag or box assemblages: a silver penny buried as a piece of money had a much greater value than a Roman copper issue, and carried a very different symbolic charge. Shifting values within modes of expression can also be detected in the burial of purses. The purse assemblage in the Mound One ship burial at Sutton Hoo may be seen as an expression of wealth at the highest social and political level in a context of the 620s or 630s; all components, including blanks and ingots, are gold, and the coins are all Merovingian tremisses. By contrast, the burials of sceattas in coin purses at Buttermarket grave 1356, Coddenham grave 8 and Finglesham grave 145 reflect a society 
with a silver monetised coinage that was accessible, and considered appropriate for funerary display, at a more modest social level.

There are strong arguments that individual economic autonomy and the personal profit motive have been under-estimated in archaeological narratives of early medieval economy and society, that there was greater social complexity and diversity below the level of ruling elites than is often allowed, and that this was especially true of the maritime trading world of the Channel and North Sea coasts. ${ }^{70}$ Aristocratic wealth and status ideology were founded on the exploitation of landed patrimony and royal service, but material wealth might also be generated through commercial activity by trader-merchants. ${ }^{71}$ It may be tempting to see in the distinction between the provision of single, perhaps symbolic, sceattas with other items of value in aristocratic graves, and the provision of coined money as the principal element of wealth in burials of individuals of apparently lower social standing, an early manifestation of these different value systems and the personal economic strategies behind them. Alternative and complementary readings are possible, however, and the contemporary or near-contemporary occurrence of both modes of provision within the cemetery at Boss Hall argues against simple and exclusive interpretations in individual cases.

The furnished graves with sceattas are overwhelmingly located on or near the coast, or close to major centres with good riverine access, and those at Buttermarket, Ipswich and St Mary's, Southampton are in cemeteries that served the precursor settlements of major 8thand 9th-century ports. ${ }^{72}$ All represent communities linked to networks of collection, redistribution and exchange as producers and consumers, but it is not possible to determine whether the coined wealth might represent the translation of a landed surplus, or social payments or obligations, or the direct result of commercial enterprise in a monetary sphere. There is a danger, too, of under-estimating at this time the extent to which degrees of autonomy were exercised within constraints of tenure, obligation and social practice, and the extent to which the ability to generate material wealth through craft or commercial specialisation was ultimately dependent upon patronage and the mobilisation of a landed surplus. We can, however, conclude with some confidence that the deposition of coined money in furnished burial does express and reflect a social recognition of new monetary circumstances in which all these options became increasingly possible to those with the necessary resources and contacts.

The very circumscribed occurrence of furnished burial with sceattas, when compared to the wider geographical spread of contemporary coin use and furnished inhumation, argues strongly that these circumstances were particularly marked in the coastal areas of southeast England, to the extent that they informed the construction and expression in burial of specific identities. This must be seen against the background of economic and monetary activity along the coastal and maritime exchange systems that linked south-east England with northern Gaul and the Low Countries. ${ }^{73}$ It is also entirely consistent with, and supports, the model of coastal- or maritime-orientated identities focussed on the network of social interactions and relationships around the Channel and North Sea coasts through which such exchange was articulated. ${ }^{74}$ The materialisation of such identities can be seen in the preferential acquisition of traded goods from at least the later 6th century, ${ }^{75}$ and in other aspects of burial practice, notably boat burial or burial with clench nails or fragments of 
boats, which may be interpreted as symbolising the importance of sea travel in peoples' lives. ${ }^{76}$ The distribution of these elements in burial is strikingly similar to that of furnished inhumations with sceattas, with clusters in eastern Kent and south-east Suffolk, and both may be represented in Coddenham grave 30 where iron clench nails were used in the construction of a wooden cover placed over the body. ${ }^{77}$ At Buttermarket, Ipswich other aspects of burial practice may also suggest that some members of the community defined elements of their identity through contacts across the North Sea and English Channel. ${ }^{78}$

The occasional deposition of coins in burials after the abandonment of furnished inhumation should be seen in a longer-term perspective. The provision of single silver pennies in later graves may represent a continuation of the rare practice of depositing single coins seen in earlier furnished burials but its symbolic function is clearly linked to, and enabled by, the common notions of value embodied in a silver denarial coinage. The provision of money in purses, pouches or bags became a feature of regular burial practice only with the inception of a silver monetary coinage and had only a short floruit during the last years of furnished inhumation. Within the tradition of formal furnished inhumation, assemblages of grave goods embodied and conveyed a range of many-stranded and linked symbolic charges, among which were statements about the worth of the individual and kin through the deposition of portable wealth. The deposition of silver pennies was the burial of portable wealth in its unequivocal monetary form, and the dead buried with purses or bags of money were being provided with items that symbolized worth in a form divested of symbolic charge bearing on other aspects of social identity. It is therefore tempting to see in this very specific and very late feature of furnished burial some indication of an understanding and acceptance of the monetization implied by the promulgation of the silver coinages. The occasional survival of this practice after the abandonment of formal furnished inhumation, as at Garton-on-the-Wolds and Spitalfields, may therefore represent the final manifestation of a symbolic element that had been a part of burial traditions in England since the middle of the 5th century.

\section{APPENDIX A: BURIALS WITH SCEATTAS}

Where images of the coins were available identifications were checked (by John Naylor) to the level used within the analysis. Images were not available for a number of finds (including, of the certain grave finds, Bridge, Broadstairs St Peter's Tip, Spitalfields and Spofforth) but in most cases the coins had been identified by experts and their attribution is unlikely to be problematic. The classification has been changed in some cases to reflect the most up-to-date scholarship. ${ }^{79}$

\section{GLOUCESTERSHIRE}

Lechlade, Butler's Field

Grave 179

Female, 35-40 years.

$1 x V a$ base metal imitation, pierced for suspension. Position in grave not recorded. 
Associated items: necklace (circular gold filigree pendant, blue glass bead on silver wire ring, 4 silver wire rings); 2 iron keys/latchlifters; fragmentary iron pin; fragments of copper-alloy sheet.

Boyle et al 1998, 130; Metcalf 2011b.

HAMPSHIRE

Southampton, Clifford Street (SOU 32)

F412

Child.

1xW. By head.

No associated finds.

Metcalf 1988, 26, 50; Morton 1992, 171-9.

Southampton, St Mary's Stadium

Grave 4202

Female, $18-25$ years.

1xBla; 1xBIb; 1xfoil impression of B obverse. Over torso.

Associated items: necklace (gold pendant, 4 silver 'bulla' pendants, 4 glass beads); knife; ?shaft of iron slide key; ?casket or box assemblage (copper-alloy 'work-box', fragments of repoussé silver-sheet disc, ?iron box or casket fitting).

Birbeck et al 2005, 33; Metcalf 2005.

KENT

Barham, Breach Down

Grave A (a small barrow excavated in 1841)

2xA3; 3xBI.

"...found lying on the right side of a skeleton, with several small brass ornaments, a large ring, a quantity of decayed wood, and a substance resembling leather." 80 
Roach Smith 1848, 7-8, PI VI 11-15; Rigold 1960, 47 (Hoard III); Meaney 1964, 111;

Richardson 2005 Vol 2, 116.

\section{Bridge}

Burials excavated by Kent Archaeological Field School in March 2005. The coin identifications given here are those by Gareth Williams. ${ }^{81}$ Grave 6 was the double burial of an adult or near-adult and juvenile but all grave goods were associated with the adult. The initial identification of other grave goods in preliminary reporting ${ }^{82}$ requires revisions and the identifications given here are from examination of the finds by Christopher Scull in September 2014. At the time of writing there has been no analysis of the human bone.

Wilkinson 2008; Williams 2008.

Grave 1

Male (grave goods).

$8 \mathrm{xA} ; 12 \mathrm{xBI} ; 1 \mathrm{x}$ ??BII. Deposited as a bag group at the foot of the grave.

Associated items: iron spearhead; copper-alloy belt-buckle; iron knife; 2 iron belt or strap mounts with copper-alloy rivets; wheel-thrown pottery vessel; ?purse or pouch group (iron buckle; iron key for mounted lock).

Grave 5

Female (grave goods).

$8 \times A ; 6 x B I$. Deposited as a bag group at the foot of the grave.

Associated items: necklet (circular gold pendant, fragment of blue glass bead); iron knife; iron chatelaine complex; glass palm cup.

Grave 6

Female (grave goods).

5xA; 7xBI. Deposited as a bag group at the foot of the burial.

Associated objects: necklet ( 2 yellow glass beads); fragmentary copper-alloy pin; fragment of iron rod; fragment of copper-alloy strip; 2 cowrie shells; 2 loomweights.

Grave 9

Female (grave goods). 
10xA; 7xBI. Deposited as a bag group at the foot of the grave.

Associated items: copper-alloy mount or strap-end; ?glass bead; iron fragments; iron ?knife; ?cowrie shell.

Broadstairs, Valletta House/Bradstow School

Grave L (excavated 1913)

Male (grave goods may suggest female), ?adult.

3xA; 4xB; 1xB (subtype unknown).

Associated items: copper-alloy buckle; iron knife; 2 iron keys or girdle hangers.

Hurd 1913; Rigold 1960, 40 (Hoard I); Meaney 1964, 111-12; Rigold and Metcalf 1984;

Richardson 2005 Vol 2, 132.

Broadstairs, St Peter's Tip

Grave 362

Female (grave goods), child or juvenile.

1xBla. By jaw.

Associated items: necklace ( 4 amethyst beads, 11 glass beads, pierced ivory disc); iron buckle; iron knife; copper-alloy chatelaine chain.

Canterbury, St Pancras Church

Grave 1 (excavated 1975)

Child.

$1 \times \mathrm{x}$.

No associated finds.

Rigold and Metcalf 1977, 38, pl III no 47; Rigold and Metcalf 1984, 249; Richardson 2005 Vol $2,133$.

Dover, Buckland

Grave 110

Female, 20-30 years. Coffined burial. 
1XPallB; 1xPallI; both looped for suspension. Associated with other necklace elements between the legs, probably in a bag.

Associated items: other necklace elements (4 glass beads and a silver wire ring); copperalloy bracelet; iron shears; iron knife; bone/antler comb and case; chatelaine complex of linked iron rods, iron keys and an iron spoon.

Rigold 1960, 51; Evison 1987, 241; Abdy and Williams 2006, 22.

\section{Finglesham}

Grave 7

Female (grave goods), 2-5 years. Coffined burial.

1xPa1A.2, looped for suspension. Element of necklace.

Associated items: other necklace elements (solidus of Sigebert II/III loped for suspension, 4 biconical gold wire beads, cyindrical gold sheet ?bead, 4 glass beads on silver wire rings, 3 silver wire rings, 2 silver 'bulla' pendants, 11 glass beads); iron knife; chatelaine complex of iron links and chain with amber amulet and 4 glass beads; copper-alloy bag or pouch fittings; wheel-thrown pottery bottle; Roman pottery flagon.

Hawkes and Grainger 2006, 35-7.

Grave 145

Male, c 21 years (with child, 3-4 years: grave-goods with adult).

1xA2; 1xA3; 2xBla; 2xBlb; 2xBlc. Purse or pouch group.

Associated items: copper-alloy purse or pouch fittings; 2 iron tools (inside pouch or purse); iron buckle; iron knife.

Rigold 1966, 1, 6 (Hoard X); Hawkes and Grainger 2006, 103-5; Abdy and Wiliams 2006, 21.

\section{Kingston Down}

Grave 15 (excavated 1959)

$1 \times D$ (type $2 c)$.

No associated finds recorded.

Rigold 1960, 35 and 53 (listed as R3, this nomenclature since replaced with Series D); Wilson and Hurst 1960, 135; Rigold and Metcalf 1984, 254. 
Sarre

Grave 226

2xPalll.

Associated items: iron knife; stud.

Brent 1868, 312; Rigold 1960, 51; Meaney 1964, 135-6; Rigold and Metcalf 1984, 261;

Richardson 2005 Vol 2, 323; Abdy and Williams 2006, 22.

Springhead

Male, 35+ years.

Grave 2129

$2 \times B I b$ at left side of waist, assumed to be in purse.

Associated items: iron spearhead.

Andrews et al 2011 Vol 1, 266, fig 5.21; Kelleher 2011, 19; McKinley 2011, 48, tab 13;

Schüster 2011, 24.

Wrotham, Bradford Platt (Quince Cottage)

Single inhumation found before 1958.

1xS; 1xT; both pierced for suspension. At neck.

No associated finds.

Meaney 1964, 141-2; Rigold and Metcalf 1977, 50, pl III nos 42-3; Rigold and Metcalf 1984, 267.

LONDON

Steward St, Spitalfields

Grave 106

?Male, $14-18$ years.

$5 \times S ; 1 \times T ; 1 x T / J$ mule; 3 unidentified (fused between other coins). Found in a purse or bag group by the right shoulder, nine of which are in three groups of fused coins. 
No associated finds.

Malcolm Lyne in Cass and Preston 2009, 62.

NORFOLK

Caistor-St-Edmund, Harford Farm

Grave 18

Female (grave goods).

1xBib; 1xBIc imitation. At head, possibly within box or casket.

Associated items: iron box fittings and padlock; iron tool; circular gold-and-garnet filigree pendant; iron shears; copper-alloy bracelet; iron pursemount/firesteel; iron and copperalloy suspension complex; copper-alloy 'work-box' and contents ( 2 copper-alloy dress hooks and silver linked-pin suite).

Penn 2000, 18-19; Blackburn 2000, 75-6.

SUFFOLK

Coddenham, Shrubland Hall Quarry

Grave 8

?Female, adult.

1xA2; 1xBib; 1xBIg. At waist, with purse or pouch complex.

Associated items: necklet (silver wire ring and 3 glass beads); copper-alloy buckle; iron knife and steel; iron ?purse fittings; copper-alloy suspension fitting and wire ring; bone/antler comb.

Penn 2011, 13-15; Metcalf 2011a.

Grave 30

Female, mature adult. Bed burial; wooden grave structure or grave lining.

Indistinct base metal imitation, series indistinguishable. In purse or pouch at knees. 
Associated items: copper-alloy hanging bowl; bone/antler comb; bag at chest and contents (2 silver toilet sets; necklace consisting of solidus of Dagobert I looped for suspension, silver wire ring with spangle and scutiform pendant, 4 silver wire rings, 2 fragmentary silver 'bulla' pendants, 2 copper-alloy wire beads, 3 bone/ivory beads, 3 amethyst beads, crystal bead, glass bead on silver wire ring, 18 glass beads; silver wire finger-ring; iron and copper-alloy chatelaine complex; iron knife; purse or pouch at knees (copper-alloy fittings) and other contents (Roman copper-alloy coin); iron shoe/garter buckles and strap-ends.

Penn 2011, 24-31; Metcalf 2011a.

Ipswich, Boss Hall

Grave 93

Female (grave goods).

1xBI. Near head, possibly within a pouch or bag, possibly as part of a box assemblage.

Associated items: 2 glass beads; iron knife; iron chatelaine components; copper-alloy bag or pouch fittings; wooden box and contents (silver toilet set; cloisonné garnet composite disc brooch; necklace or necklaces consisting of solidus of Sigebert III looped for suspension, 4 circular gold pendants, 2 gold cabochon garnet pendants, 2 cast silver beads, 2 silver wire beads, silver sheet bead, glass bead on silver wire ring, 5 glass beads).

Scull 2009a; Archibald 2009, 101.

Grave 2014/2 (excavated during evaluation in 2014)

Female (grave goods).

2xBIb; 2xBla-c; 1xBI?g. In bag at waist.

Associated items: silver wire ring; chatelaine complex with iron and copper-alloy links and iron keys.

Sommers 2015.

Ipswich, Buttermarket

Grave 1356

?Male (grave goods)

1xPalll; 1xPalll base metal imitation. In purse at waist.

Associated items: purse (copper-alloy fittings) and other contents ( 2 iron tools); iron buckle; 2 iron knives. 
Scull 2009a, 140-1; Archibald 2009, 241-2.

Grave 4275

Female, adult. Wood-lined grave.

1xPalll base metal imitation; $1 x^{\prime}$ Constantine' base metal imitation; both looped for suspension as part of a necklace buried in a bag in the area of the pelvis.

Associated items: bag ?fittings and contents (fragmentary copper-alloy pin; fragments of iron ?pin; other necklace components consisting of 2 silver wire rings, at least 14 silver 'bulla' pendants and a glass bead; 2 garnet settings and 17 fragments of uncut garnet); iron knife; iron chatelaine complex; copper-alloy fittings from an organic box or container.

Scull 2009a, 152-4; Archibald 2009, 241-2.

NORTH YORKSHIRE

Garton Slack 1, Garton-on-the-Wolds

Grave 2

2xG; 2xJ (type 85); 2xJ (type 37); 1xK (type 32a); 1xR3var (listed by Rigold as R2z). Under left side of pelvis, probably in a pouch or bag.

No associated items.

Rigold 1960, 49 (Hoard VIII); Grantham and Grantham 1966; Grierson and Blackburn 1986, tab 13; Geake 1997, 158; Metcalf 1994, 510.

Spofforth, Village Farm

Grave 227

Female, adult. Chest burial.

1xY (Eadberht of Northumbria 737-58).

Associated items: iron chest fittings; iron key.

NAA 2002; Craig-Atkins 2012, 331.

APPENDIX B: SCEATTAS LESS CERTAINLY OR POSSIBLY FROM BURIALS 
ESSEX

Southend-on-Sea, Thorpe Bay

Found in brick-earth digging, with or near a skeleton, at Thorpe Hall brickfield in 1929. There is no record of other grave goods or burials. Accounts of the discovery are inconsistent and some suggest that there may have originally been 20 coins.

1xA3; 2xBII; 3xC1; $2 x C 2$ (listed in the references as R1a and R1b respectively; re-labelled as C1/C2 in Metcalf 1993, 106-7).

Rigold 1960, 48 (Hoard VI); Rigold and Metcalf 1984, 263.

HAMPSHIRE

Southampton, Marine Parade (SOU 13)

Uncertain context: possibly from a grave, or pit or later settlement context.

$1 \times C$

Metcalf 1988, 26, 37; Morton 1992, 136.

KENT

Out Elmsted, Barham

Two sceattas and a spear were exhibited 'during the war' but the sceattas are now lost.

Rigold 1960, 8 (footnote 1).

Birchington

Found before 1848. Contra Rigold and Metcalf ${ }^{83}$ there is no evidence that this was necessarily a grave group rather than unstratified material found at the same time or place.

Rigold 1960: 1xBII; 1xR1; 2xR3 (=D type 2c)

Rigold and Metcalf 1984: 1xBII; 1xC; 2xD

Roach Smith 1848, 64; Rigold 1960 48-49 (Hoard VII); Rigold and Metcalf 1984, 247;

Richards 2005 Vol 2, 9-10.

Faversham, ?King's Field

Pre-1893 "from graves at Faversham, Kent".

$1 \times B 1$ 
Pale gold shilling (clasped hands/Concordia Militum) pierced for suspension.

Payne 1893, 311; Rigold and Metcalf 1984, 251; Richardson 2005 Vol 2, 35; Gannon 2013, 41-42.

Milton Regis (Cook's Lane)

Found in 1916 during brick-earth digging.

$8 \times A ; 12 \times B$.

Anon 1926; Rigold 1960, 47 (Hoard II); Hawkes and Grove 1963; Meaney 1964, 128; Rigold and Metcalf 1984, 256; Webster and Backhouse 1991, 54-5; Richardson 2005 Vol 2, 52-3.

Ozengell

$1 \times B I f, 1$ or $2 x B$

Found during railway construction 1845-50. W.H. Rolfe was able to acquire finds from the railway workers and to undertake some excavation. Roach Smith, describing Rolfe's collection from Ozengell, records three sceattas and a gold coin of Justinian from burials and illustrates one sceatta and the gold coin - a solidus of Justinian I now in the British Museum. ${ }^{84}$ However, Wright's account of finds made at Ozengell during a visit in 1847 also states that in a grave found the previous year 'the deceased had been buried with his purse, which contained two of the early Saxon coins called sceattas, and a gold Byzantine coin...of the Emperor Justin' ${ }^{85}$ There is no further information about the provenance of these finds or their associations but the identification of the burial as male may suggest that there were grave goods other than a purse and coins.

Roach Smith 1854, 2-18, pls I-VI; Wright 1854, 82; Rigold 1960, 47 (Hoard IV); Meaney 1964, 131; Metcalf 1984, 193; Rigold and Metcalf 1984, 257; Richardson 2005 Vol 2, 63, 294-5; Abdy and Williams 2006, 33.

NORFOLK

Caister-on-Sea

2 sceattas were retrieved from the cemetery area (Area 4) during Charles Green's 1951-55 excavations but neither can be attributed to a specific grave: 1xD, 1xJ (type 37). The latter is listed as 'in or over top-filling of grave'. Coins from Caister-on-Sea as listed by Rigold and Metcalf ${ }^{86}$ appear to have mixed the finds and their findspots, and so the BI listed there as a possible grave find is probably wrongly assigned.

Darling and Gurney 1993, 69, 252.

Kings Lynn 
In 1993 Metcalf referred to a then recent grave-find (Series E) 'from the Kings Lynn area' but gave no further details. ${ }^{87}$ In 2010, he and Op den Velde provided more details: the 'find' consisted of 21 sceattas which came onto the coin market in London. ${ }^{88}$ After searching for more information it appeared that they may have come from 'somewhere in the vicinity of Kings Lynn'. One of the sceattas was a late Secondary Phase Series R11, the others all Primary Phase (1XA, 3xB, 4xC, 1xA/C imitation, 1xF, 1xBZ, 1xZ/type 66, 3xE) with the exception of a single Secondary Phase Series $E$. The earlier 20 coins were considered a possible grave find on the grounds that '[t]wenty was a conventional number for a (late) grave-find' (see above for our critique of this position), although the possibility that they could have formed a non-funerary hoard was admitted. Assuming the 20 coins formed a single deposit their composition is considerably more varied than any other grave deposit but is consistent with two recent Norfolk hoards, from Aldborough and Loddon. ${ }^{89}$ There would appear to be no evidence nor any reason to consider this a grave find.

Residual CoIns from Grave Fills

A coin from Repton (Derbyshire) grave 524 (Series J) was found among the bones of the hand but the excavator considers that it may have been residual; a coin from North Elmham (Norfolk) grave 187 (Series R2) is considered residual..$^{90}$

\section{BIBLIOGRAPHY}

Abdy, R and Williams, G 2006 'A catalogue of hoards and single finds from the British Isles C AD 410-675.' In Cook and Williams, 11-73.

Andrews, P, Biddulph, E, Hardy, A. and Brown, R 2011 Settling the Ebbsfleet valley. High Speed 1 excavations at Springhead and Northfleet, Kent: the Iron Age, Roman, Saxon and medieval landscape. Volume 1: the sites, Oxford and Salisbury: Oxford Wessex Archaeology

Andrews, P, Mepham, L, Schüster, J and Stevens C, 2011 Settling the Ebbsfleet valley. High Speed 1 excavations at Springhead and Northfleet, Kent: the Iron Age, Roman, Saxon and medieval landscape. Volume 4: Saxon and later finds and environmental reports, Oxford and Salisbury: Oxford Wessex Archaeology

Anon, 1926: 'Anglo-Saxon jewels from Kent', Antiq J 6, 446-7.

Archibald, M 2009 'Coins', in Scull 2009a, 101, 241-2.

Bates, D and Liddiard, R (eds) 2013 East Anglia and its North Sea World in the Middle Ages, Woodbridge: Boydell.

Biddle, M, Blunt, C, Kjølby-Biddle, B, Metcalf, M and Pagan, H 1986 'Coins of the AngloSaxon period from Repton, Derbyshire: II', Brit Numis J 56, 16-33.

Birbeck, V, Smith, R, Andrews, P and Stoodley, N 2005 The origins of Mid-Saxon Southampton: Excavations at the Friends Provident St Mary's Stadium 1998-2000, Salisbury: Wessex Archaeology. 
Blackburn, M 2000 'The two sceattas of Series B from Grave 18', in Penn, 75-6.

Blackburn, M 2003 '"Productive" sites and the pattern of coin loss in England, 600-1180', in Pestell and Ulmschneider, 20-36.

Blackburn, M 2011 'Coinage in its archaeological context', in Hamerow et al, 580-99.

Bonser, M 2011, 'The 'North of England' productive site revisited', in T Abramson (ed.), Studies in Early Medieval Coinage volume 2: new perspectives, Woodbridge: Boydell, 159-80.

Boyle, A, Jennings, D, Miles, D and Palmer, S 1998 The Anglo-Saxon Cemetery at Butler's Field, Lechlade, Gloucestershire Volume 1: Prehistoric and Roman Activity and Anglo-Saxon Grave Catalogue, Oxford: Oxford Archaeology.

Boyle, A, Jennings, D, Miles, D and Palmer, S 2011 The Anglo-Saxon Cemetery at Butler's Field, Lechlade, Gloucestershire Volume 2: The Anglo-Saxon Grave Goods, Specialist reports, Phasing and Discussion, Oxford: Oxford Archaeology.

Brent, J 1868: 'Account of the Society's researches in the Anglo-Saxon cemetery at Sarr', Archaeol Cantiana 7, 307-21.

Brookes, S 2007 'Boat-rivets in graves in pre-Viking Kent: reassessing the Anglo-Saxon boat burial traditions', Medieval Archaeol 51, 1-18.

Brugmann, B 2004 Glass Beads from Early Anglo-Saxon Graves, Oxford: Oxbow.

Cass, S and Preston, S 2009 'Roman and Saxon burials at Steward Street, Tower Hamlets', Trans London Middlesex Archaeol Soc 60, 53-72.

Cook, B and Williams, G (eds), Coinage and History in the North Sea World c AD 500-1250: Essays in Honour of Marion Archibald, Leiden: Brill.

Craig-Atkins, E 2012 'Chest burial: a middle Anglo-Saxon funerary rite from northern England', Oxford J Archaeol 31.3, 317-336.

Cramp, R 2005 Wearmouth and Jarrow monastic sites, London: English Heritage.

Crawford, S 2011 'Overview: the body and life course', in Hamerow et al, 626-40.

Darling, M and Gurney, D 1993 Caister-on-Sea excavations by Charles Green, 1951-55. East Anglian Archaeol Rep 60.

Dickinson, T M 2011 'Overview: mortuary ritual' in Hamerow et al, 221-37. 
Dijkstra, M F P, De Koning, J and Lange, J 2006, Limmen 'De Krocht'. De opgraving van een middeleeuwse plattelandsnederzetting in Kennemerland, Amsterdam: AmsterdamAAC / Projectenbureau.

Evison, V I 1979 Wheel-Thrown Pottery in Anglo-Saxon Graves, London: Royal Archaeological Institute.

Evison, V I 1987 Dover: The Buckland Anglo--Saxon Cemetery, Hist Build Monuments Comm Engl Archaeol Rep 3.

Fleming, R 2009, 'Elites, boats and foreigners: rethinking the rebirth of English towns', in Città e campagna nei secoli altomedievali 1, 393-425, Settimane de Studio del Centro Italiano sull'Alto Medievo 56.

Gannon, A 2003, The Iconography of Early Anglo-Saxon Coinage. Sixth to eighth centuries, Oxford: Oxford University Press.

Gannon, A 2013 Sylloge of Coins of the British Isles 63. British Museum Anglo-Saxon coins 1. Early Anglo-Saxon Gold and Anglo-Saxon and Continental Silver Coinage of the North Sea Area, c. 600-760, London: British Museum Press.

Gilchrist, R 2008 'Magic for the dead? The archaeology of magic in later medieval burials', Medieval Archaeology 52, 119-59.

Geake, H 1992 'Persistent problems in the study of conversion-period burials in England', in S Lucy and A Reynolds (eds), Burial in Early Medieval England and Wales, 144-55, Soc Medieval Archaeol Monogr Ser 17.

Geake, H 1997 The use of Grave-Goods in Conversion-Period England, c $600-c$ 850, Brit Archaeol Rep Brit Ser 261.

Grantham, C and Grantham, E 1966 'An earthwork and Anglian cemetery at Garton-on-theWolds, East Riding, Yorkshire', Yorkshire Archaeol J 41, 355-360

Grierson, P and Blackburn, M 1986 Medieval European Coinage with a Catalogue of Coins in the Fitzwilliam Museum Cambridge, Volume 1: the Early Middle Ages (5th-10th Centuries), Cambridge: Cambridge University Press.

Härke, H 1992a Angelsächsische Waffengräber des 5. bis 7. Jahrhunderts, Zeitshrift für Archäologie des Mittelalters 6.

Härke, H 1992b 'Changing symbols in a changing society: the Anglo-Saxon weapon burial rite in the seventh century', in M Carver (ed), The Age of Sutton Hoo: the Seventh Century in North-Western Europe, 149-165, Woodbridge: Boydell. 
Hamerow, $\mathrm{H}$ with Byard, A, Cameron, E, Düring, E, Levick, $\mathrm{P}$, Marquez-Grant, $\mathrm{N}$ and Shortland, A 2015 'A High-Status Seventh-Century Female Burial from West Hanney, Oxfordshire', Antiq J 95, 1-28.

Hamerow, H, Hinton, D A and Crawford, S (eds) 2011 The Oxford Handbook of Anglo-Saxon Archaeology, Oxford: Oxford University Press.

Hamerow, H, Ferguson, C and Naylor, J 2013, 'The origins of Wessex pilot project', Oxoniensia 78, 49-69.

Hawkes, S and Grove, L 1963 'Finds from a seventh-century Anglo-Saxon cemetery at Milton Regis', Archaeol Cantiana 78, 22-38.

Hawkes, S and Grainger, G 2006 The Anglo-Saxon Cemetery at Finglesham, Kent, Oxford Univ School Archaeol Monogr 64.

Hill, D and Metcalf, D M (eds) 1984, Sceattas in England and on the Continent. The Seventh Oxford Symposium on Coinage and Monetary History, British Archaeol Rep Brit Ser 128.

Hills, C 2011 'Work boxes or reliquaries? Small copper-alloy containers in seventh century Anglo-Saxon graves', in S Brookes, S Harrington and A Reynolds (eds), Studies in Early AngloSaxon Art and Archaeology: Papers in Honour of Martin G Welch, 14-9, British Archaeol Rep Brit Ser 527.

Hines, J 2010 'Units of account in gold and silver in seventh-century England: scillingas, sceattas and paeningas' Antiq J 90, 153-73.

[Hines and Bayliss eds] Bayliss, A, Hines, J, Nielsen, K H, McCormac, G and Scull, C J 2013 Anglo-Saxon Graves and Grave-goods of the 6th and 7th Centuries AD: a Chronological Framework, Soc Medieval Archaeol Monogr Ser 33.

Huggett, J 1988 'Imported grave goods and the early Anglo-Saxon economy', Medieval Archaeol 32, 63-96.

Hurd, H 1913 Some Notes on Recent Archaeological Discoveries at Broadstairs, Broadstairs Kelleher, R 2011 'Saxon and medieval coins' in Andrews et al Vol 4, 19-21.

Kent, J P C 1987 'The coins', in Evison 1987, 180-1.

King, M D 1988 'Roman coins from early Anglo-Saxon contexts', in J Casey and R Reece (eds), Coins and the Archaeologist (second edition), 225-9, London: Seaby.

Lebeq, S 1997 'Routes of change: production and distribution in the West (5th-8th century)', in L Webster and M Brown (eds), The Transformation of the Roman World AD 400-900, 6778, London: British Museum Press. 
Loveluck, C P 2013 Northwest Europe in the Early Middle Ages, c AD 600-1150: a Comparative Archaeology, Cambridge, Cambridge University Press.

Loveluck, C P and Tys, D 2006 'Coastal societies, exchange and identity along the Channel and southern North Sea shores of Europe', J Maritime Archaeol 1(2), 140-69.

Lucy, S 2000 The Anglo-Saxon Way of Death: Burial Rites in Early England, Stroud: Alan Sutton.

Lucy, S 2011 'Gender and gender roles', in Hamerow et al, 688-703.

McKinley, J, 'Human bone from Springhead', in Andrews et al Vol 4, 47-9.

Marsden, A 2013, 'Three recent sceatta hoards from Norfolk', Norfolk Archaeol 46, 492-502.

Meaney, A 1964 A Gazetteer of Early Anglo-Saxon Burial Sites, London: Allen and Unwin.

Metcalf, D M 1984 'Twenty-five notes on sceatta finds' in Hill and Metcalf (eds), 193-205.

Metcalf, D M 1988 'The coins', in P Andrews (ed) The coins and pottery from Hamwic, Southampton: Southampton City Museum, 17-59.

Metcalf, D M 1993 Thrymsas and Sceattas in the Ashmolean Museum Oxford Volume 1, London: Royal Numismatic Society and Ashmolean Museum Oxford.

Metcalf, D M 1994 Thrymsas and Sceattas in the Ashmolean Museum Oxford Volume 3, London: Royal Numismatic Society and Ashmolean Museum Oxford.

Metcalf, D M 2005 'Coins', in Birbeck et al, 55-6.

Metcalf, D M 2011a 'The Anglo-Saxon sceattas in Graves 8 and 30', in Penn, 62.

Metcalf, D M 2011b 'An imitative Vanimundus sceat', in Boyle et al, 85-6.

Metcalf, D M and Op den Velde, W 2010, 'The monetary economy of the Netherlands, c 690-c 760 and the trade with England: a study of the 'porcupine' sceattas of series E. Volume II', Jaarboek voor Munt- en Penningkunde 97, 285-506.

Morton, A D 1992 Excavations at Hamwic Volume 1: Excavations 1946-83, excluding Six Dials and Melbourne Street, Counc Brit Archaeol Res Rep 84.

NAA (Northern Archaeological Associates) 2002 Cemetery Excavations at Village Farm, Spofforth, North Yorkshire. Archaeological Post-Excavation Assessment, (Unpublished NAA report).

Naylor, J 2003 An Archaeology of Trade in Eastern England. c 650-900CE, unpublished PhD thesis, University of Durham. 
Naylor, J 2012 'Coinage, trade and the origins of the English emporia', in S Gelichi and R Hodges (eds), From One Sea to Another: Trading Places in the European and Mediterranean Early Middle Ages, 237-66, Turnhout: Brepols.

Naylor, J 2013 'Portable antiquities and other finds in the Upper Thames Valley', in H Hamerow, C Ferguson and J Naylor, 'The Origins of Wessex pilot project', Oxoniensia 78, 4969, 51-9.

Op den Velde, W, De Boone, W J and Pol, A 1984, 'A survey of sceatta finds from the Low Countries', in Hill and Metcalf (eds), 117-145.

Op den Velde, W, and Klaassen, C J F, 2004, Sceattas and Merovingian Deniers from Domburg and Westenschouwen, Werken uitgegeven door het Koninklijk Zeeuwsch Genootschap der Wetenschappen 15.

Payne, G 1893 'Anglo-Saxon antiquities of D.F. Kennard of Linton near Maidstone', Proc Soc Antiq London 2nd series 14, 311-314.

Penn, K 2000 Excavations on the Norwich Southern Bypass, 1989-91 Part II: The Anglo-Saxon Cemetery at Harford Farm, Caistor St Edmund, Norfolk. E Anglian Archaeol Rep 92.

Penn, K 2011 The Anglo-Saxon Cemetery at Shrubland Hall Quarry, Coddenham, Suffolk, East Anglian Archaeol Rep 139.

Pestell, T 2003 'The afterlife of "productive" sites in East Anglia', in Pestell and Ulmschneider, 122-37.

Pestell, T and Ulmschneider, K 2003 Markets in Early Medieval Europe. Trading and 'Productive' sites, 650-850, Macclesfield: Windgather.

Reynolds, A 2009 Anglo-Saxon Deviant Burial Customs, Oxford: Oxford University Press.

Richardson, A 2005 The Anglo-Saxon Cemeteries of Kent, Brit Archaeol Rep Brit Ser 391.

Rigold, S E 1960 'The two primary series of English sceattas', Brit Numis J 30, 6-53.

Rigold, S E 1966 'The two primary series of English sceattas: addenda and corrigenda', Brit Numis J 35, 1-6.

Rigold, S E 1968 'The post-Roman coins.' In B Cunliffe (ed) Fifth Report on the Excavations of the Roman Fort at Richborough, Kent, 217-223, Rep Res Comm Soc Antiq London 23.

Rigold, S E 1974 'Coins found in Anglo-Saxon burials', in J Casey and R Reece (eds), Coins and the Archaeologist, Brit Archaeol Rep Brit Ser 4, 201-5. 
Rigold, S E 1980 'The sceattas', In P Wade-Martins, Excavations in North Elmham Park 19671972, 497-99, E Anglian Archaeol Rep 9.

Rigold, S E and Metcalf, D M 1977 'A check-list of English finds of sceattas', Brit Numis J 47, 31-52.

Rigold, S E and Metcalf, D M 1984 'A revised check-list of English finds of sceattas', in Hill and Metcalf (eds), 245-268.

Roach Smith, C 1848: Collectanea Antiqua, Volume 1, London: Privately Printed.

Roach Smith, C 1854: Collectanea Antiqua, Volume 3, London: Privately Printed.

Schüster, J 'Saxon objects', in Andrews et al Vol 4, 23-37.

Scull, C J 1990 'Scales and weights in early Anglo-Saxon England', Archaeol J 147, 183-215.

Scull, C J 1993 'Archaeology, early Anglo-Saxon society and the origins of Anglo-Saxon kingdoms', Anglo-Saxon Stud Archaeol Hist 6, 65-82.

Scull, C J 2001 'Burials at emporia in England', in D Hill and R Cowie (eds), Wics: the Early Medieval Trading Centres of Northern Europe, 67-74, Sheffield Archaeol Monogr 14.

Scull, C J 2002 'Ipswich: development and contexts of an urban precursor', in B Hårdh and L Larsson (eds), Central Places in the Migration and Merovingian Periods. Papers from the 52nd Sachsensymposium, Lund, August 2001, 303-16, Uppåkrastudier 6.

Scull, C J 2009a Early Medieval (Late 5th-Early 8th Centuries AD) Cemeteries at Boss Hall and Buttermarket, Ipswich, Suffolk, Soc Medieval Archaeol Monogr Ser 27.

Scull, C J 2009b 'The human burials', in S Lucy, J Tipper and A Dickens, The Anglo-Saxon Settlement and Cemetery at Bloodmoor Hill, Carlton Colville, Suffolk, 385-426, E Anglian Archaeol Rep 131.

Scull, C J 2013a 'Burial practice in Anglo-Saxon England', in Hines and Bayliss eds, 523-9.

Scull, C J 2013b 'Ipswich: contexts of funerary evidence from an urban precursor of the seventh century $A D^{\prime}$ ', in Bates and Liddiard (eds), 218-229.

Scull C J 2015 'Chronology, burial and conversion: the case of England in the 7th century', in C Ruhmann and V Brieske (eds), Dying Gods: Religious Beliefs in Northern and Eastern Europe in the Time of Christianisation, 00-00, Neue Studien zur Sachsenforshung 6.

Sommers, M 2015 East of England Co-op Dairy Site, Boss Hall, Sproughton Road, Ipswich, Suffolk IPS 735. Archaeological Evaluation Report, Suffolk County Council Archaeological Service Rep 2014/101. 
Stoodley, N 1999 The Spindle and the Spear: a Critical Enquiry into the Construction and Meaning of Gender in the Early Anglo-Saxon Burial Rite, Brit Archaeol rep Brit Ser 288.

Stoodley, N 2011 'Childhood to old age', in Hamerow et al, 641-66.

Webster, L and Backhouse, J 1991 The Making of England. Anglo-Saxon Art and Culture AD 600-900, London: British Museum Press.

White, R 1988 Roman and Celtic Objects from Anglo-Saxon Graves: a Catalogue and an Interpretation of their Use, Brit Archaeol Rep Brit Ser 191.

Wilkinson, P 2008 The Archaeological Investigation of a Hexagonal Feature at Star Hill, Bridge, near Canterbury, Kent, 2003-6, Faversham: Kent Archaeological Field School.

Williams, G 2006 'The circulation and function of coinage in conversion-period England, c AD 580-675', in Cook and Williams, 145-192.

Williams, G 2008 '224. Bridge, Kent. Four Anglo-Saxon graves with coins and associated objects', in R Bland (ed) Treasure Annual Report 2005/6, 81, London: British Museum and Department of Culture, Media and Sport.

Williams, G 2010 'Anglo-Saxon gold coinage. Part 1: the transition from Roman to AngloSaxon coinage', Brit Numis J 80, 52-75.

Williams, G 2013 'The circulation, minting, and use of coins in East Anglia, c AD 580-675', in Bates and Liddiard (eds), 120-36.

Williams, H 2011 'Mortuary practices in early Anglo-Saxon England', In Hamerow et al, 23865.

Wilson, D and Hurst, J 1960 'Medieval Britain and Ireland in 1959', Medieval Archaeol 4, 134-65.

Worrall, S, Egan, G, Naylor, J, Leahy, K and Lewis, M (eds) 2010 A decade of discovery: proceedings of the portable Antiquities Scheme conference 2007. Brit Archaeol Rep Brit Ser 520.

Wright, T 1854 Wanderings of an Antiquary; chiefly upon the Traces of the Romans in Britain, London: J B Nichols and Sons.

Zedelius, V 1988, 'Eighth-century archaeology in the Meuse and Rhine valleys: a context for the sceatta finds' in D M Metcalf (ed), Coinage in Ninth-century Northumbria, British Archaeol Rep Brit Ser 180, 405-13.

ACKNOWLEDGEMENTS 
Our thanks are due to all those who gave us access to, or information on, unpublished material: Craig Bowen (Canterbury Heritage Museum), Sue Brunning (British Museum), Corinne Duhig (McDonald Institute for Archaeological Research, University of Cambridge) Richenda Goffin and Mark Sommers (Suffolk Archaeology), Paul Johnson (Northern Archaeological Associates), Faye Minter (Suffolk County Council), Andrew Richardson (Canterbury Archaeological Trust) and Paul Wilkinson (SWAT Archaeology). Our thinking has benefitted from discussion with colleagues including Marion Archibald, Pieterjan Deckers, John Hines, Andrew Woods and Gareth Williams, and we should like to thank the two referees for their comments. Responsibility for opinions expressed, however, rests with us.

\section{FIGURE CAPTIONS}

FIG 1

Burial sites with furnished graves containing Pre-Primary Phase sceattas. Drawing by Kirsty Harding

FIG 2

Burial sites with furnished graves containing Primary Phase sceattas. Drawing by Kirsty Harding

FIG 3

Burial sites with unfurnished graves containing Primary Phase or Secondary Phase sceattas. Drawing by Kirsty Harding

FIG 4

Distribution of Series A sceattas. Drawing by Kirsty Harding

FIG 5

Distribution of Series BI and BX sceattas. Drawing by Kirsty Harding

FIG 6

Chart comparing the proportions of stray finds and burial finds of early Primary Phase sceattas in East Kent. Drawing by John Naylor

FIG 7

Chart comparing the proportions of stray finds and burial finds of early Primary Phase sceattas within $20 \mathrm{~km}$ of Ipswich, Suffolk. Drawing by John Naylor

FIG 8

Coin iconography and burial symbolism. All coins except (a) are single finds recorded by the Portable Antiquities Scheme which are representative of the type and are not coins from burials.

(a) Imitative Constantine/Pallb mule, looped for suspension- Buttermarket cemetery, Ipswich, grave 4275. (b) Series Va- PAS SF-53F2C1. (c) Series Palll- PAS CAM-C598B2. (d) Series Bla- PAS SF-FA26D5. (e) Series A3- PAS SUSS-58CCB0. (f) Series W- PAS LVPL-5E4380. Scale 2:1. 
Photographs: (a) I Leonard, (C) Society for Medieval Archaeology/Historic England, (b) F Minter, (c) H Fowler, (d) T Plunkett, (e) S Smith (f) V Oakden.

\section{TABLE CAPTIONS}

TAB 1

Burials with sceattas showing numbers and series represented in each grave.

TAB 2

Summary of chronological information for burials with sceattas.

\section{NOTES}

${ }^{1}$ Prof Christopher Scull, Cardiff School of History, Archaeology and Religion, Cardiff University, John Percival Building, Colum Drive, Cardiff CF10 3EU. ScullCJ@cardiff.ac.uk

${ }^{2}$ Dr John Naylor, National Finds Advisor for Medieval and Post-Medieval Coinage, Heberden Coin Room, Ashmolean Museum of Art and Archaeology, University of Oxford, Beaumont Street, Oxford OX1 2PH. john.naylor@ashmus.ox.ac.uk

${ }^{3}$ Rigold 1960; 1966; 1974.

${ }^{4}$ eg Archibald 2009; Blackburn 2000; Kent 1987; Metcalf 2005; 2011a, b; Penn 2011, 61-2.

${ }^{5}$ Compare Rigold 1974 and Blackburn 2011, 591-3.

${ }^{6}$ Hines and Bayliss eds 2013.

7 < https://finds.org.uk> [accessed 21 February 2015]; Worrall et al 2010.

8 Williams 2006, 2010, 2013; cf Hines 2010; Scull 1990.

${ }^{9}$ Rigold 1974; Geake 1997, 32.

${ }^{10}$ Gannon 2013, 95-136 provides the most up-to-date survey of the coinage; see also Grierson and Blackburn 1986, 155-89 although the 'Intermediate' phase is now generally divided between Primary and Secondary phases.

11 Gannon 2013, 93-8.

12 Gannon 2013, 51-3, fig 2.

13 Gannon 2013, fig 2.

14 Gannon 2013, 100.

${ }^{15}$ Hines and Bayliss eds 2013.

${ }^{16}$ Hines and Bayliss eds 2013, 493-515.

17 The picture may be complicated by the fact some early Anglo-Saxon burial sites became locations for later middle Anglo-Saxon activity such as meeting places or periodic markets and so unstratified coin finds from the vicinity of a known burial site need not be from graves: Hamerow et al 2013, 59.

18 Roach Smith 1854, 2-18; Payne 1893, 311.

${ }^{19}$ Roach Smith 1848, 64.

${ }^{20}$ Anon 1926; Hawkes and Grove 1963; Webster and Backhouse 1991, 55.

${ }^{21}$ Dickinson 2011, 228-32; Geake 1997; Scull 2013a, 526.

22 Geake 1997; Hines and Bayliss eds 2013; Lucy 2000; Stoodley 1999.

${ }^{23}$ Scull 2013a, 526-8. 
${ }^{24}$ Hines and Bayliss eds 2013.

25 The base imitation from Coddenham grave 30 is too corroded to be attributed to type but is overwhelmingly likely to represent a Pre-Primary or Primary Phase type given the other finds from the grave.

26 Payne 1893, 311; Gannon 2013, 41-2; Abdy and Williams 2006, 73 (cat. no. 329).

27 PAS BM-7C4457.

28 Pierced sceattas are rare and unusual finds with PAS recording only five examples from its overall corpus of almost 800 sceattas. See PAS records NARC-E843F2, HESH-C9EF2A, YORYM-6652B4, SOM-8325A1 and DENO-808377). Interestingly, all are outside the core areas for sceatta distributions.

${ }^{29}$ Geake 1997, 9; Scull 2009a, 114.

${ }^{30}$ Archibald 2009, 101.

${ }^{31}$ Metcalf 1988, 26, 50; 1993, 155-6.

32 Morton 1992, 171-9; Scull 2001, 69-72; 2013a, 527-8.

${ }^{33}$ Hines and Bayliss eds 2013, 462-5, Fig 8.3.

${ }^{34}$ This figure is a combined total using finds from the Portable Antiquities Scheme (PAS; www.finds.org.uk) and Corpus of Early Medieval Coin Finds (EMC; www. fitzmuseum.cam.ac.uk/dept/coins/emc) plus a number of excavation finds.

35 Naylor 2012, 252-4,

${ }^{36}$ For the Gloucestershire Cotswolds and Oxfordshire, PAS and EMC list only 16 finds of Series $\mathrm{A}, \mathrm{BX} / \mathrm{BI}$ and $\mathrm{F}$. For a general discussion of coin circulation in the Upper Thames Valley see Naylor 2013, 57-8.

37 Penn 2000, 101-4; Blackburn 2003, 28, 35; Pestell 2003, 130-1.

38 Geake 1997, map 1; Hines and Bayliss 2013, figs 10.5, 10.9.

${ }^{39}$ Naylor 2003, 251-3; Bonser 2011.

40 PAS YORYM-9A8ED1.

${ }^{41}$ Boyle et al 1999, 130, figs 5.31, 5.101; Metcalf 2011b, 86.

${ }^{42}$ Williams 2006; 2010, 57-9.

${ }^{43}$ Archibald 2009, 242.

${ }^{44}$ Metcalf 2011b.

${ }^{45}$ White 1988, 101; Geake 1997, 32.

${ }^{46}$ Metcalf 2005, 56.

${ }^{47}$ Reynolds 2009, 121.

48 Geake 1992, 147-8; 1997, 128; Hines and Bayliss eds 2013, 476-9; 529-543.

49 Härke 1992 a, b; Hines and Bayliss eds 2013, 541-3; Scull 2009b, 422-3.

${ }^{50}$ Crawford 2011; Dickinson 2011; Härke 1992a; Lucy 2011; Stoodley 1999; 2011; Williams 2011.

51 Loveluck 2013, 178-212; 361-3; Lucy 2000, 174-86; Scull 1993, 72-3; Stoodley 1999, 126 35;

52 Härke 1992b; Hine and Bayliss eds 2013, 541-3; Scull 2009b, 422-3.

53 Below, 00-00; Loveluck and Thys 2006; Loveluck 2013, 178-212; 361-3.

54 Geake 1997; Härke 1992b; Hines and Bayliss eds 2013, 529-45.

${ }^{55}$ Craig-Atkins 2012.

56 Gannon 2003, 9; Gilchrist 2008, 149.

57 Gannon 2003, 107-10, 136-8.

58 Hills 2011.

59 Metcalf 1988, 26 for this interpretation for Clifford Street. 
${ }^{60}$ Rigold 1960, 8.

${ }^{61}$ For example, Rigold 1974, 204; Metcalf 1984, 194; 2005, 56; 2011a, 62; Metcalf and Op Den Velde 2010, 289-90; Blackburn 2011, 592; Kelleher 2011, 19.

62 Metcalf 2011a, 62.

${ }^{63}$ Metcalf 2005, 56.

${ }^{64}$ Kings Lynn is also most unlikely. See Appendix B for discussion.

65 Geake 1997, 32 38-9; Williams 2006, 161-9.

66 Hines 2010; Scull 1990; Williams 2006, 2010, 2013.

67 Hamerow 2015; Scull 2015.

${ }^{68}$ Scull 2009b, 391-3, 410.

69 King 1988; White 1988, 100-1.

70 Lebecq 1997; Loveluck 2013, 178-212; Naylor 2012.

71 Loveluck 2013, 212, 361-3.

72 Birbeck et al 2005; Scull 2001; 2002; 2009a.

${ }^{73}$ Although outside our geographical scope it should be noted that sceattas are known from burials on long-distances Continental routes, for instance at coastal locations such as

Domburg and Limmen, Netherlands (Op den Velde and Klaasen 2004, 5; Dijkstra et al 2006, $85-88$ ) and along the Rivers Rhine and Meuse (Zedelius 1988; Op den Velde et al 1984, 11820; Metcalf and Op den Velde 2009, fig. 7.20).

74 Loveluck and Tys 2006; Fleming 2009; Loveluck 2013, 178-212.

75 Huggett 1988; Evison 1979, 48-65, maps 1-3; Brugmann 2004, 37-40, figs 60-1.

76 Brookes 2007.

77 Penn 2011, 41-2.

78 Scull 2009a, 293-4; 2013b.

${ }^{79}$ Gannon 2013.

${ }^{80}$ Roach Smith 1848, 7.

81 Williams 2008.

82 Wilkinson 2008.

83 Rigold and Metcalf 1984, 247.

${ }^{84}$ Roach Smith 1854; Abdy and Williams 2006, 33,

${ }^{85}$ Wright 854, 82. Metcalf 1984, 193 notes these discrepancies.

86 1984, 248.

${ }^{87}$ Metcalf 1993, 196.

${ }^{88}$ Metcalf and Op Den Velde 2010, 289-90.

89 Marsden 2013.

${ }^{90}$ Biddle et al 1986, 29; Rigold 1980; Blackburn 2000, 75-76. 